\title{
COVID-19 pandemic's broadcast media messages' consumption in rural community and behavioral change
}

\author{
Blessed F. Ngonso ${ }^{\text {a,1,*}, ~ O b i n n a ~ J o h n k e n n e d y ~ C h u k w u ~}{ }^{\text {b,2 }}$ \\ ab Km7, Auchi-Abuja Road, Iyamho-Uzairue Edo State, Nigeria \\ ${ }^{1}$ ngonso.frederick@edouniversity.edu.ng *; ${ }^{2}$ chukwu.obinna@edouniversity.edu.ng \\ * corresponding author
}

\section{ARTICLE INFO}

Article history

Received 2020-09-14

Revised 2020-09-29

Accepted 2021-01-08

Keywords

COVID-19 Pandemic

Broadcast Media

Messages' Consumption

Rural Community

Behavioral Change

\section{ABSTRACT}

This study adopts FGDs as a research method. The discussion process was conducted in four different quarters that make up the community with 25 participants. Four research questions were formulated to guide the course of the investigation. The study's findings showed that many community members are exposed to media messages on COVID-19 through the television. The results also showed that the community people, particularly the educated ones, watch TV on cable (GOTV and Startimes), and these are the people who shared information with family members, interpret it and take positive actions. While those who cannot read or write watch local NTA Auchi. These persons are few and mainly among the illiterate who source for news in the local language. A smaller proportion of the sample also affirmed that they do not watch TV or listen to COVID-19 information due to hunger. This group maintained that they only watch the Zee World channel. The findings also showed that no group talked about radio with emphasis. Therefore, it is agreed that the rural community people in Iyamho do not depend on radio for information, including COVID-19 information. In conclusion, the researchers agreed that rural dwellers of Iyamho are exposed to COVID-19 information on TV, and the story has shaped their behavior by their interpretation of the messages received. The researchers also conclude that radio is no longer fashionable in the rural community. Therefore, it is recommended that subsequent studies on rural dweller's media message consumption should painstakingly interrogate the influence of social media. Again, in the future, if there is a need for a health awareness campaign, the government and health agencies should consider the use of traditional media to pass the information across to rural dwellers since illiterate folks still exist in the rural communities. TV information on health matters should be translated into rural languages on TV stations on GOTV and Startimes cables.

This is an open access article under the CC-BY-SA license.

\section{Introduction}

COVID-19 pandemic has recalibrated the hitherto world order and subjected everybody to learning new methods of survival. Information dissemination and communication-related activities are not left out in the new arrangement [1]. Hence, the need to ascertain and distinguish how the rural dwellers accessed and interpreted the COVID-19 pandemic's broadcast messages [2]. The Corona Virus outbreak started in Wuhan province of China, in December 2019. In its earliest report, World Health Organisation (WHO) acknowledged that the virus is novel and phenomenal and that 
the body (WHO) is still studying and learning the mannerisms, patterns, and modes of transmission of the virus [3]. However, it asserts that the transmission is based on a human to human. WHO further outlined several measures to curb the spread of the deadly virus, which it later designated as a pandemic and named COVID-19 [4]. The measures include - Social distancing, regular washing of hands with water and soap, and alcohol-based sanitizers [5].

Despite the above measures and the lockdowns that enveloped the world, the virus has spread to over 182 countries, with more than five million infected persons and over 200,000 deaths [6]. United States of America remains the epicenter, for now, and accounts for more than half of the world's infection and mortality [7]. With over 20000 infected persons and over 200 deaths, Nigeria remains the highest in Sub-Saharan Africa. Edo State, one of the States in Nigeria, accounts for 200 infected persons and over 20 deaths [8]. Scientists have agreed that Nigeria is yet to reach its peak or flatten the COVID-19 curve and that information and adherence to the measures outlined by the WHO and NCDC remain the leeway to arresting the spread of the virus. Scholars also agree that data is the bulwark of the development of society [9]. Islam and Ahmed state in support that information is conceived as an essential resource that contributes immensely towards the development of a nation [10]. They argued further that, ideally, the announcement brings about knowledge and a knowledgeable community is also an informed community. This, by extension, signifies that a society cannot develop without experience, and a community can only become knowledgeable if they recognize and use information as to their tool for development.

The above portends that access to the right information by rural communities and dwellers can help them to acquire the skills, confidence to participate fully in community affairs, and the knowledge and to learn requisite for thriving in the pandemic era [11]. Moore asserts in agreement that: Information is a crucial contributor to the development of individuals and communities. People need the information to develop their potential through education and training, succeed in business, enrich their cultural experience, and take control of their daily lives.

Further, Sharma and Fatima noted that access to quality information would help rural dwellers fight against superstitious beliefs and help them become better citizens [10]. Similarly, World Bank [12] admonished policymakers to see rural dwellers as citizens equally entitled to amenities (information on measures against the spread of COVID-19, inclusive), like their urban counterparts. Despite the above prescriptions, Zijp and Correa, in their respective studies, espoused the rural dwellers' information difficulties [13]. The two researchers assert that rural dwellers have difficulty locating and having access to the needed information in a timely fashion; rural communities do not always know what their information needs are; how can they meet their needs, and from where they can get their required information.

Despite the above difficulties, asserts in support of this informatory role of the media thus, that as the society grows large, the people will depend on the media to get information that changes cognitions, overcome provincialism and enhances cosmopolitanism [14]. In the same vein, broadcast media are said to possess the ability and capacity to jump geographical boundaries, break the barriers of illiteracy, the immediacy of information dissemination, low degree of economic strain compared to the other media, and contributed immensely in making the world a global village [15]. Iredia sees broadcast media as a vibrant occupation of glamour and a subject that virtually everyone is familiar with [16]. He further said that it is not difficult to define broadcasting. Indeed, whenever broadcasting is mentioned, most people consciously or subconsciously relate to their radio and television sets from which they receive broadcast signals every day in their homes and offices. The question is, did the broadcast media in Edo State, in spite of the above beautiful attributions, disseminate information bothering on the COVID-19 pandemic to the rural dwellers? What broadcast media were the rural dwellers in Iyamho exposed to? How did the rural dwellers in Iyamho receive and interpret the information bothering on COVID-19? Amongst others. In others words, the study aims at finding out whether the broadcast media in Edo State, capped with the above-adumbrated sterling potentials, performed the informatory role by disseminating information bothering on the COVID-19 pandemic, and to ascertain and assess the extent and interpretation given to such information by the rural dwellers in Iyamho and how the behavioral change influenced by the performance of the information received. This study is, however, limited to radio and television (public and private, operating in analog or digital mode and situated) in Edo State, Nigeria. 


\section{Theorical Framework}

\subsection{Media Health Information and Rural Dwellers' Behavioral Change}

The mass media exist in diverse forms, such as social and digital, print, broadcast, and outdoor media. Each media form exists to disseminate messages that entertain, inform, educate, correlate, and persuade the people across boundaries. Ball-Rokeach asserts that the media play important roles in attracting people by providing necessary information. Media messages increase and improve audiences' knowledge of health-related issues, government programs, agricultural innovation, entrepreneurial development, and social cum welfare programs [17]. In a similar vein, Ndolo, Eze, and Nwodo, citing Olujimi and Adekunle, state that "the mass media have cardinal responsibilities which amongst others are to inform, educate, and as well mobilize people for actions [18]. Through well-planned media campaigns, with obvious messages and necessary awareness will herald increased knowledge, positively influence attitude and ultimately engender proper practice", Ezegwu and Nzekwe tend to support Ndolo, Eze, and Nwodo as they also state that, "knowledge influences attitude and positive attitude culminates into practice. Therefore, it is essential that campaigns inform adequately, paying particular attention to barriers that hinder adoption of the desired behavior." [19].

Knowledge is essential in all sectors of human endeavors because, with experience, the right attitude will become possible. But the wisdom that will lead to behavior change is so much desire in matters related to health because low health awareness, knowledge, and behavior change are dangerous to society [20]. The rural areas, particularly in Nigeria, have constantly been denied access to health facilities and information relevant to their health needs part because most of the health-related projects and broadcast media that disseminate health information are cited in the urban areas. Okonkwo captures it this way, "unfortunately, the repressive visibility which the national media and their operative conveyed upon them remained persistent [21]. This is because the ruralites have never had a chance to be part of the program creativity and planning or production process". It is important to note that a high level of awareness on health-related matters in a time like this (COVID-19 pandemic season) speaks volumes about the status of health literacy in Nigeria. Ndolo, Eze, and Nwodo opined that "health literacy is important because there is consistent evidence indicating an association between health literacy, health behavior, and health outcomes [18]. People with low levels of individual health literacy are many and three times more likely to experience an adverse outcome". They also cited Kanj and Miti who outlined some importance of health literacy in the society thus:

1. A large number of people affected: Some countries within the EMR have high adult literacy rates. However, approximately half have a percentage below the global developing country average of 79 percent. In most EMRO countries, literacy rates are lower among women than a men-the exception being Qatar and UAE.

2. Poor health outcomes: There is a clear correlation between inadequate health literacy-as measured by reading fluency-and increased mortality rates.

3. In EMR, chronic diseases are estimated to account for almost half (47\%) of the disease's total burden. Health literacy plays a crucial role in chronic conditions (such as COVID19) self-management.

As we have seen, information remains a potent tool for health behavior change. The broadcast media, therefore, have a responsibility to disseminate health information bordering on COVID- 19 . The radio, for instance, is a powerful medium in terms of information dissemination and persuasion. According to FAO and Hasbullah cited in Didiugwu, radio remains the most important medium for communicating to the rural people [22]. Isiaka asserts "that radio has been used for training, awareness creation, enlightenment, and entertainment" [23], Oso states that "65-70\% African population consist of those who live in the rural areas and have low-level literacy and urban life pattern'. He also says that radio as a mass medium could readily catalyze social mobilization, social orientation and attitudinal change among Nigerian populace to the prevention and treatment of malaria in the country [24].

while radio has sound, television content includes both sound and visuals. This audio-visual television character makes it a magic medium that allows us to watch the world from our drawing rooms. This powerful visual nature helps television create vivid impressions in our minds, which 
leads to emotional involvement. The audio-visual quality also makes television images more memorable" [23]. Television, as a means of communicating with rural people, is still a significant challenge. Rural television has been attempted without appreciable success. One way of solving the problem is the establishment of television viewing centers in various communities. TV can penetrate areas that are inaccessible to man either for logistical or cultural reasons. In other words, TV gets across barriers. But the primary attribute of TV is the appeal of sight and sound.

\subsection{Household Consumption of the Broadcast Media Messages}

Before the advent of social media, families usually sit around radio and television to listen to local and national news and another program, particularly entertainment-oriented programs such as wrestling, football match, movies, and soaps [25]. Specifically, television brings family members together in their sitting room, where they sit and watch programs. Most times, family members come together to watch the program if they have foreknowledge of the program's airing time and if the program is their favorite. Studies have also shown that families always sit together to watch TV in the evening, where most members are back from work [26]. TV viewership rating is therefore measured per household based on the number of TV sets. In Nigeria, records show that $40 \%$ of households have TV sets. According to the Trading Economy report, "Households with television are the share of households with a television set. Some countries report only the number of households with a color television set, and therefore the true number may be high actual reported" [27]. This report further revealed that: According to the World Bank collection of development indicators, households with a television in Nigeria were reported at $40 \%$ in 2010, compiled from officially recognized sources. Nigeria - Households with television - actual values, historical data, forecasts, and projections were sourced from the World Bank in July of 2020 [28]. It is also believed that when people are too anxious about their wellbeing, they tend to depend on the media for information in one hand. On the other hand, when people are confined to a place, they rely more on mass media such as radio and television to escape route for their boredom.

\section{Method}

The researchers used Focus Group Discussions (FGDs) research method to conduct this research. This method allows the researchers to investigate the subjects in their natural setting. Qualitative data were, therefore, gathered using (FGDs) interview. This instrument was deemed useful in this study because of the nature of respondents (rural people). It is believed that FGDs (talk) is the best kind of instrument for the collection of data from the rural populace because of the notion that many of the rural people may not be able to read and write to fill a questionnaire for the survey. The researchers interviewed 25 members of the community in four different groups. To be part of the interview's FGDs, the researchers accepted only those between the age of 15 to 70 years who were physically strong and could sit for 15 minutes. The community has four quarters, namely, Iyomila, Iyobie, Iyola, and Iyaba (source: Oral source, from the community). Based on this division, the researchers decided to conduct FGDs in each of the quarters to capture the community members' fair representative opinion on the COVID-19 pandemic's broadcast media messages consumption and behavioral change. The radio stations situated in Edo are as follows :

93.7 - SilverBird Rhythm FM, Ugbowo, Benin City

92.3 - Independent Radio, Glass House, Airport Road, Benin City, Edo State

95.775 - Edo Broadcasting Service, Aduwawa, Benin City

105.5 - RayPower FM, Ikhuen Niro, Benin City

100.1 - Uniben FM (University of Benin Radio), Benin City

101.5 - Bronze FM (FRCN), WAEC Road, Aduwawa, Benin City

796.9 - Speed FM, Old Azagba Road, Eyean, Benin City

92.7 - KU FM, Benin-Auchi Expressway, Benin City

90.5 - Okada Wonderland FM, [Igbinedion University Radio] Okada

111.5 - Esan FM, Ewu 
94.1 - Hillside FM [Auchi Polytechnic Radio], Auchi

1297.3 - Vibes Fm, No. 1, Osadeba Street off Adesuwa Road, G.R.A, Benin-City, Edo

Television stations situated in Edo State include:

ITV - Benin, Glass House, Airport Road, Benin City. Frequency- N/A

NTA - Benin, West Circular Road, PMB 1117, Benin City. Frequency - 189.25 MHz

NTA Auchi, Auchi, Nigeria. Frequency - N/A

NTA Iruekpen, NTA Iruekpen, Ireken, Edo. Frequency - Channel 45 UHF

Edo State Broadcasting Corporation TV, Benin, Nigeria. Frequency - 55 UHF

AIT, Benin\}

For this research, we delimit our questions to find out rural dwellers' COVID-19 information consumption on radio and the following on the list above- 2,3,6,7,8,9,10,11 and for TV stations, 1 , $2,3,4$ and 5 stated above. In conducting this research, the researchers explained their purpose for the interview and solicited for their co-operation. The FGDs were more conversational to create a friendly atmosphere for easy and tension free discussion and get in-depth responses from the participants. The responses were recorded and afterward transcribed for purposes of qualitative analysis [29].

\section{Results and Discussion}

Discussion of findings was done in line with the four research questions presented below:

1) Local media outfits situated in Edo State, Nigeria, disseminate information bothering on the COVID-19 pandemic

The result from the descriptive data presented above showed that local TV (NTA, Auchi) carried information on COVID-19. However, the data showed that NTA Auchi is the only local broadcast medium they rural dweller tuned to get information on the Coronavirus. The rural dwellers in Iyamho prefer TV stations on GOTV and Startimes (AIT, NTA, and Channels TV). During the COVID-19 lockdown, we do watch TV stations on cable, not local stations. We do watch these stations sometimes to look for information on COVID-19. We have heard the news on COVID-19 from these cable stations. The information we've got make us believe that COVID-19 exists. Several times, I have discussed the story with my family members (a significantly older man who happens to be the house owner where the FGDs took place emphasized). The information has made me keep social distancing and avoid handshaking. One group member emphatically said that she has never listened to the radio or watch TV because of COVID-19.

2) Particular broadcast medium do rural dwellers in Iyamho exposed to during the lockdown for COVID-19 information

The result from the descriptive data also showed that the Iyamho people do not want some much watch local channels because most of them use cable; therefore, they prefer other media. The result and direct observation during FGDs meetings, the two groups that had their TV on were watching movie stations (Zee World and AMC). However, a group had confirmed that the only TV that they watched is NTA, Auchi. We will like to say that many people do not believe that COVID-19 exists in Nigeria. The reason is that we have watched on TV how people died in European countries and America, but in Nigeria, we do not know the names of those killed by COVID-19. All we hear is that someone is positive and has been discharged, and another person is positive and is dead. Some governors and their family members will test positive today, tomorrow they will recover, and these stories leave us in doubt about the existence of COVID-19 in Nigeria. However, in this community, most are not literate, which affects their ability to rely on the media for any information. We think that the educated ones are those who depend on the media for information. We have cable (GOTV and Startimes in our homes), but we mainly watch AIT/NTA, Channels TV. Those who use Startimes like to manage NTA Auchi because NTA also reads the local language news. Some of us do not depend on radio and television but social media and our phones since we receive text messages from Nigeria Centre for Disease Control (NCDC) always (a particular middle-aged man explained). Yes, we do find information on TV. We do also share our feelings on the news with our 
family members. One significant action we have taken in this community due to the media's information is the use of hand sanitizer and hand watches. You can even see it in people's houses around here.

\section{3) The rural dwellers in Iyamho receive and interpret the broadcast messages on COVID-19}

The answer to this question is yes. The descriptive data showed that Iyamho rural dwellers received information on COVID-19 from the media, particularly the TV on their cable-GOTV and Startimes. We do not have time for anything COVID-19. We were so bothered with what to eat, hunger everywhere. My boyfriend had even stopped giving me money (a particular lady in the group complained). We have never switched over from this our Zee World channel to any other for any reason. We only hear COVID-19 and lockdown from people.

4) The interpreted messages influence their behavior towards COVID-19

The findings of this study also showed that they interpret the message differently. Some still believe that Coronavirus does not exist. This group of persons does not take the note seriously, while those who thought that the Coronavirus is real interpreted the message positively, resulting in keeping to the Federal Government and Nigeria Centre for Disease Control guidelines such as social distancing, use of hand sanitizers, and washing of hands with running water. This group is the educated ones who depend on the media for information on the Coronavirus. We watch mainly NTA Auchi to get information on COVID-19. We do share this information with our family members. Aside from NTA Auchi, our brothers and sister in the cities call us to tell us more about the Coronavirus, so we become more conscious and curious about COVID-19. The information has helped us to take proactive measures about COVID-19. We keep the rules of NCDC through the information we got from NTA Auchi. Sometimes we even pray about it, asking God to take it away.

\section{Conclusion}

This study adopts FGDs as a research method. The discussion process was conducted in four different quarters that make up the community with 25 participants. The study's findings showed that a large portion of the community members is exposed to media messages on COVID-19 on television. The descriptive data earlier presented also showed that the community people, particularly the educated ones, watch TV on cable (GOTV and Startimes), and these are the people who shared information with family members, interpret it, and take positive actions. Our result is also in line with Ndolo, Eze, and Nwodo, they opined that "health literacy is important because there is consistent evidence indicating an association between health literacy, health behavior, and health outcomes. People with low levels of individual health literacy are many and three times more likely to experience an adverse outcome [30]. While those who cannot read or write watch local NTA Auchi. These persons are few and mainly among the illiterate who source for news information in the local language. The findings also showed that no group talked about radio with emphasis. Therefore, it is agreed that the rural community people in Iyamho do not depend on radio for information, including COVID-19 information. In conclusion, the researchers decided that rural dwellers of Iyamho are exposed to COVID-19 details on TV, and the story has shaped their behavior by their interpretation of the messages received. This is premised on the fact that the rural people of Iyamho placed water cans and hand sanitizers in their houses and also maintained social distancing. The researchers also concluded that radio is no longer fashionable in the rural community of Iyamho. This may be attributed to many community members having access to cable TV and constant electricity to power it. Therefore, it is recommended that subsequent studies on rural dwellers media message consumption should painstakingly interrogate the place of social media. Again, in the future, if there is a need for a health awareness campaign, the government and health agencies should consider the use of traditional media to pass the information across to rural dwellers since illiterate folk still exist in the rural communities. Such news and information concerning the health issue should be translated into rural languages and air on TV stations on GOTV and Startimes cables. 


\section{References}

[1] Y. Z. Y, "Information presentation and media performance in COVID-19 's report," The Press, pp. 12 $15,2020$.

[2] J. Zhao, C. Chen, and L. Zhao, "The spread characteristics of music videos relating to COVID-19 in China online video platforms," Int. J. Commun. Soc., vol. 2, no. 1, pp. 1-11, Jun. 2020, doi: 10.31763/ijcs.v2i1.94.

[3] W. C. Culp, "Coronavirus Disease 2019," A A Pract., 2020, doi: 10.1213/xaa.0000000000001218.

[4] Worldometer, "Coronavirus Cases," Worldometer, 2020. .

[5] W. Guan et al., "Clinical characteristics of coronavirus disease 2019 in China," N. Engl. J. Med., 2020, doi: 10.1056/NEJMoa2002032.

[6] N. Zhu et al., "A novel coronavirus from patients with pneumonia in China, 2019," N. Engl. J. Med., 2020, doi: 10.1056/NEJMoa2001017.

[7] S. Hernandez, S. O'Key, A. Watts, B. Manley, and H. Pettersson, "Tracking COVID-19 cases in the US," CNN, 2020. [Online]. Available: https://edition.cnn.com/interactive/2020/health/coronavirus-usmaps-and-cases/.

[8] The Nigeria Centre for Disease Control (NCDC), "COVID-19 NIGERIA," The Nigeria Centre for Disease Control (NCDC), 2020. [Online]. Available: https://covid19.ncdc.gov.ng/.

[9] S. Oyekanmi, "Coronavirus Nigeria's COVID-19 curve is flattening at a rapid pace," Nairametrics, 2020. [Online]. Available: https://nairametrics.com/2020/08/31/nigerias-COVID-19-curve-isflattening/.

[10] M. S. Islam and S. M. Z. Ahmed, "The information needs and information-seeking behaviour of rural dwellers," IFLA J., vol. 38, no. 2, pp. 137-147, Jun. 2012, doi: 10.1177/0340035212444513.

[11] OECD Policy Responses to Coronavirus (COVID-19), "Policy implications of Coronavirus crisis for rural development," OECD Policy Responses to Coronavirus (COVID-19), 2020. [Online]. Available: http://www.oecd.org/coronavirus/policy-responses/policy-implications-of-coronavirus-crisis-for-ruraldevelopment-6b9d189a/.

[12] S. Adhikari, "COVID-19 is reducing domestic remittances in Africa: What does it mean for poor households?" World Bank Blog, 2020. [Online]. Available: https://blogs.worldbank.org/africacan/COVID-19-reducing-domestic-remittances-africa-what-does-itmean-poor-households.

[13] Oyesola, "Rural Dwellers Perception On Effect Of Infrastructural Facilities On Livelihood Activities In Akinyele Local Government Area Of Oyo State, Nigeria," J. Rural Econ. Dev., vol. 16, pp. 1-10., 2017, doi: 10.22004/ag.econ.147637.

[14] C. Happer and G. Philo, "The Role of the Media in the Construction of Public Belief and Social Change," J. Soc. Polit. Psychol., vol. 1, no. 1, pp. 321-336, Dec. 2013, doi: 10.5964/jspp.v1i1.96.

[15] P. E. Okon, "Changes in media policy in Sub-Saharan Africa: the role of community media," Edinburgh Napier University, 2014.

[16] I. Tonnie, "Broadcast Management in Nigeria: The systems approach as an imperative," J. Bus. Manag., vol. 17, no. 12, pp. 26-33, 2015, doi: 10.9790/487X-171232633.

[17] S. J. Ball-Rokeach and M. L. DeFleur, "A Dependency Model of Mass-Media Effects," Communic. Res., vol. 3, no. 1, pp. 3-21, Jan. 1976, doi: 10.1177/009365027600300101.

[18] O. Chinanuife, P. Eze, and O. Nwodo, "Public debt spiral and domestic investment in Nigeria," Acad. J. Econ. Stud., vol. 4, no. 1, pp. 153-156, 2018.

[19] Ezugwu, M. Ifeyinwa, and G. N. Nzekwe, "INFLUENCE OF BREAST CANCER BROADCAST MEDIA CAMPAIGNS ON THE HEALTH BEHAVIOUR OF WOMEN IN SOUTH-EAST NIGERIA,” J. Media Stud., vol. 9, no. 1, pp. 190-201, 2015.

[20] A. Odorume, "MASS MEDIA HEALTH COMMUNICATION: IMPERATIVE FOR SUSTAINABLE HEALTH DEVELOPMENT IN NIGERIA,” Mgbakoigba J. African Stud., vol. 4, pp. 1-6, 2015. 
[21] A. Foley, “Okonkwo's fate and the worldview of Things Fall Apart," Literator, vol. 22, no. 2, pp. 3960, Aug. 2001, doi: 10.4102/lit.v22i2.361.

[22] I. F. Didiugwu, "The Role of Social Media in Future Elections in the 21st Century Africa," New media mass Commun., vol. 41, pp. 87-95, 2015.

[23] I. Alimi, A. Shahpari, V. Ribeiro, N. Kumar, P. Monteiro, and A. Teixeira, "Optical wireless communication for future broadband access networks," in 201621 st European conference on networks and optical communications (NOC), 2016, pp. 124-128.

[24] L. Oso and B. Semiu, "The Concept and Practice of Corporate Governance in Nigeria: The Need for Public Relations and Effective Corporate Communication," J. Commun., 2012, doi: 10.1080/0976691x.2012.11884790.

[25] F. F. Lotan, "Making a positive internet through Socmed Agawe Guyub," Int. J. Commun. Soc., vol. 1, no. 1, pp. 9-16, 2019, doi: 10.31763/ijcs.v1i1.22.

[26] D. Lee, "Living room TV is 'making a comeback', says Ofcom,” BBC News, 2013. [Online]. Available: https://www.bbc.com/news/technology-23521277.

[27] Trading Economics, "Households With Television By Country," Trading Economics, 2020. [Online]. Available: https://tradingeconomics.com/country-list/households-with-television-percent-wb-data.html.

[28] World Bank, "Nigeria - Households With Television," Trading Economics, 2020. [Online]. Available: https://tradingeconomics.com/nigeria/households-with-television-percent-wb-data.html.

[29] P. Shamdasani and D. Stewart, Focus Groups: Theory and Practice. London: Sage Publication, 2014.

[30] A. F. Wali, "Broadcast Media and Rural Mobilization: Did it help the Ebola Awareness Campaign in Nigeria?,” J. Mass Commun. Journal., vol. 08, no. 04, 2018, doi: 10.4172/2165-7912.1000378. 